\title{
TANGENCIÁLIS ÉS RADIÁLIS VÍZSUGARAS ESZTERGÁLÁSSAL MEGMUNKÁLT FELÜLETEK ÉRDESSÉGE ALUMÍNIUM ÖTVÖZETEN
}

\author{
Kun-Bodnár Krisztina \\ egyetemi tanársegéd, Miskolci Egyetem, Gyártástudományi Intézet \\ 3515 Miskolc, Miskolc-Egyetemváros, e-mail: krisztina.bodnar@uni-miskolc.hu \\ Maros Zsolt \\ egyetemi docens, Miskolci Egyetem, Gyártástudományi Intézet \\ 3515 Miskolc, Miskolc-Egyetemváros, e-mail: zsolt.maros@uni-miskolc.hu
}

\begin{abstract}
Absztrakt
Az abraziv vízsugaras esztergálás egy új technológia a nehezen megmunkálható forgásszimmetrikus munkadarabok megmunkálására. Kétféle eljárás van elterjedöben: a tangenciális és a radiális módszer. A vízsugárral történö esztergálás egyik problémája, hogy a vágás valódi fogásmélysége nem egyezik meg a beállitott értékkel. A radiális és tangenciális eljárás ugyanazon technológiai paraméterek beállítása esetén eltérö anyagleválasztást és felületminöséget eredményez. A cikkben egy aluminium ötvözet kétféle vízsugaras esztergálással megmunkált felületeinek érdességét hasonlitjuk össze annak érdekében, hogy megállapitsuk az egyes eljárások elönyeit, hátrányait és elsösorban egymáshoz való viszonyát.
\end{abstract}

Kulcsszavak: vizsugaras esztergálás, tangenciális és radiális eljárás, felületi érdesség

\begin{abstract}
Abrasive waterjet turning is a new technology to machine cylindrical or axisymmetric parts from hard to machine materials. There are two methods spread out for waterjet turning: tangential and radial method. One of the problems of waterjet turning is that the real depth of cut usually is not equal with the adjusted depth of cut. The radial and tangential processes result differences in surface quality when the same technological parameters are set. In this paper, we compare the roughness of the surfaces of an aluminium alloy machined by two types of waterjet turning in order to determine the advantages, disadvantages and, above all, their relationship to each other.
\end{abstract}

Keywords: waterjet turning, tangential and radial method, surface roughness

\section{Bevezetés}

A vízsugaras megmunkálások egy nem hagyományos technológia, melyeket napjainkban egyre szélesebb körben alkalmaznak. Ezen technológiák közül az egyik az abrazív vízsugárral történő esztergálás, mely lehetővé teszi forgásszimmetrikus alkatrészek, mint hengeres vagy kúpos felületek előállítását olyan anyagokból, melyek hagyományos esztergálással nem munkálhatók meg.

Vízsugaras esztergálásnál a munkadarab $\mathbf{v}_{\mathrm{fc}}$ sebességgel forog, miközben a sugár tengelyirányban $\mathrm{V}_{\mathrm{fa}}$ sebességgel mozog. Tangenciális esztergálásnál a sugár egy adott mélységben, radiális eljárásnál a munkadarab fölött, annak szimmetria tengelyében van elhelyezve (1. ábra). A kialakuló fogásmélység $\left(a_{p}\right)$ mindkét esetben számtalan tényező eredményeként jön létre $[1,2]$ 


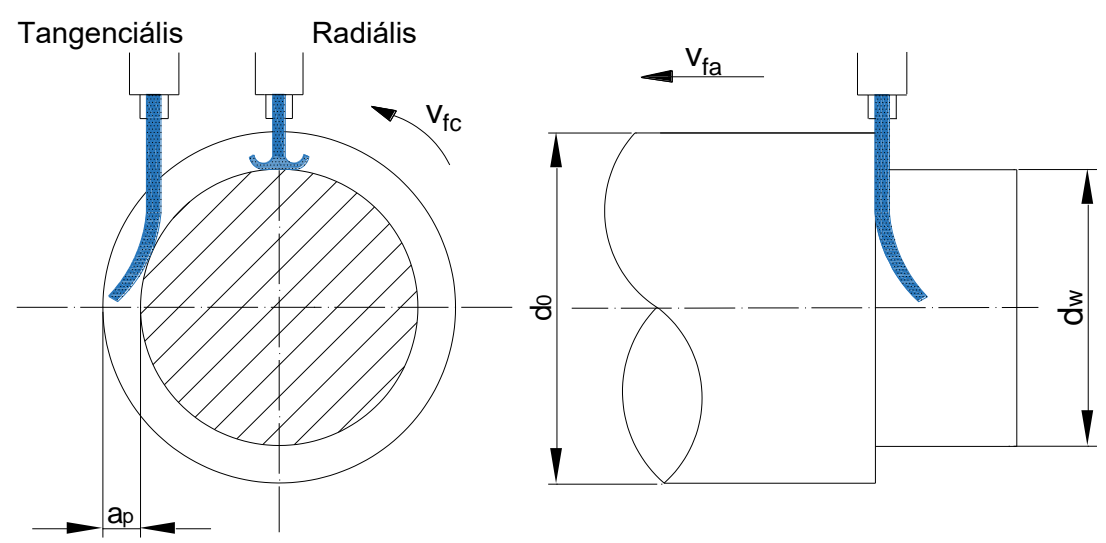

1. ábra. Tangenciális és radiális abrazív vizsugaras esztergálás kinematikai vázlata

Az anyagleválasztás a sugárban lévő abrazív por, víz és levegő keveréke hatására jön létre. Vízsugaras vágásnál nagyon kicsi a vágóerő, ami lehetővé teszi hosszú és viszonylag kis átméröjü alkatrészek vágását $[3,4]$. Az eljárás alkalmas rideg és nehezen vágható anyagok, mint például üveg, kerámia, kompozitok, illetve különböző szuper- vagy titánötvözetek vágására [5,6,7].

\section{Kísérleti körülmények, vizsgálati eszközök}

A kísérlet során $\mathrm{AlMg} 0,7 \mathrm{Si}$ jelü alumínium ötvözet felületét munkáltuk meg abrazív vízsugaras esztergálással.

\subsection{Forgatóberendezés és megmunkáló gép}

A kísérletek elvégzéséhez kifejlesztettünk egy forgatóberendezést (2. ábra), melyet egy CORTINA DS2600 típusú, kétkoordinátás abrazív vízsugaras vágógépre szereltünk fel.



2. ábra. Megtervezett és elkészitett forgatóberendezés 
A forgatóberendezést [8] az alábbi szempontoknak megfelelően terveztük meg és készítettük el:

- vízsugaras berendezésen legyen végrehajtható a megmunkálás és az alapgép biztosítsa az előtolást

- a készülék felfogása stabil legyen

- biztosítsa a munkadarab befogását és a forgómozgást

A berendezés három föbb egységből áll: hajtómü, vízvédő szerkezet és tartószerkezet.

\subsection{A megmunkált felületek érdességének mérése}

A megmunkált felületek érdességének mérését a Miskolci Egyetem Gyártástudományi Intézetének egyik laboratóriumában végeztük el az AltiSurf 520 háromdimenziós felülettopográfiai berendezésen (3. ábra).

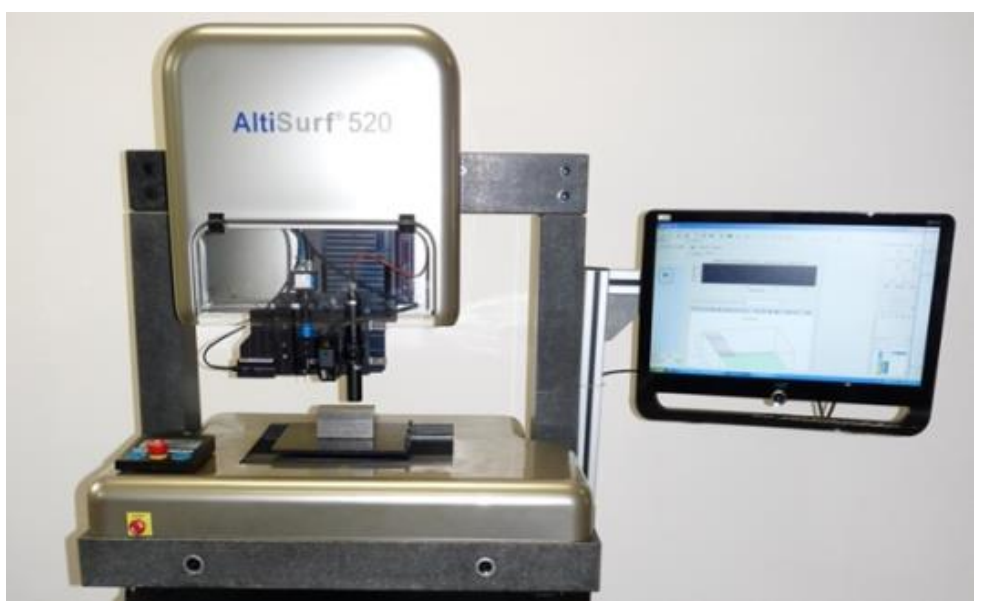

3. ábra. AltiSurf 520 háromdimenziós felülettopográfiai berendezés

A megmunkálást követően profil és térbeli érdességi jellemzőket is meghatároztunk a felületek érdességének jellemzésére.

A megmunkált felületek szemrevételezéséhez a felületekről ZEISS Stereo Discovery.V8 mikroszkópon (4. ábra) készítettünk fotókat.

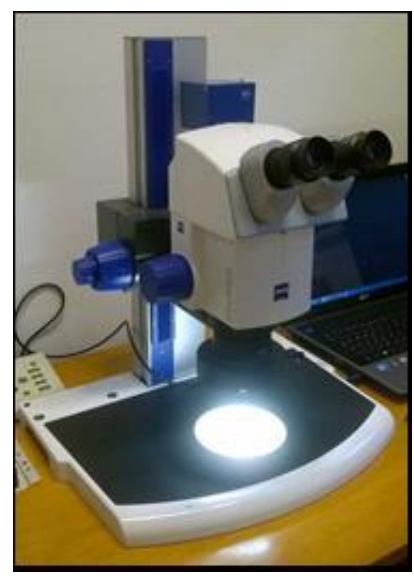

4. ábra. ZEISS Stereo Discovery.V8 mikroszkóp 


\subsection{Kísérleti beállítások}

A forgácsolási kísérletek elvégzése során a víznyomást állandó értéken tartottuk, változtattuk az előtoló sebesség és a munkadarab fordulatszámának nagyságát. A beállítási adatokat az 1. táblázat mutatja.

1. táblázat. Kisérleti beállitások paraméterei

\begin{tabular}{|c|c|c|c|c|c|c|}
\hline \multicolumn{7}{|c|}{ AlMg0,7Si } \\
\hline Próbatest & \multirow{2}{*}{ sugár } & \multirow{2}{*}{ Kísérlet } & abrazív tömegáram & nyomás & motor fordulat & elötolás \\
\hline sorszáma & & & $\mathrm{g} / \mathrm{min}$ & bar & ford/min & $\mathrm{mm} / \mathrm{min}$ \\
\hline \multirow{2}{*}{1.} & 1. (érintő irányú) & 1. & 400 & 3000 & 200 & 10 \\
\hline & 2. (sugár irányú) & 2. & 400 & 3000 & 200 & 10 \\
\hline \multirow{2}{*}{2.} & 1. (érintő irányú) & 3. & 400 & 3000 & 200 & 5 \\
\hline & 2. (sugár irányú) & 4. & 400 & 3000 & 200 & 5 \\
\hline \multirow{2}{*}{3.} & 1. (érintő irányú) & 5. & 400 & 3000 & 200 & 2 \\
\hline & 2. (sugár irányú) & 6. & 400 & 3000 & 200 & 2 \\
\hline \multirow{2}{*}{4.} & 1. (érintő irányú) & 7. & 400 & 3000 & 100 & 15 \\
\hline & 2. (sugár irányú) & 8. & 400 & 3000 & 100 & 15 \\
\hline \multirow{2}{*}{5.} & 1. (érintő irányú) & 9. & 400 & 3000 & 100 & 10 \\
\hline & 2. (sugár irányú) & 10. & 400 & 3000 & 100 & 10 \\
\hline \multirow{2}{*}{6.} & 1. (érintő irányú) & 11. & 400 & 3000 & 300 & 5 \\
\hline & 2. (sugár irányú) & 12. & 400 & 3000 & 300 & 5 \\
\hline \multirow{2}{*}{7.} & 1. (érintő irányú) & 13. & 400 & 3000 & 300 & 3 \\
\hline & 2. (sugár irányú) & 14. & 400 & 3000 & 300 & 3 \\
\hline \multirow{2}{*}{8.} & 1. (érintő irányú) & 15. & 400 & 3000 & 300 & 2 \\
\hline & 2. (sugár irányú) & 16. & 400 & 3000 & 300 & 2 \\
\hline
\end{tabular}

Ugyanazon technológiai paraméterekkel, egy próbadarabon végeztünk vízsugaras esztergálási kísérleteket a radiális és tangenciális beállítás mellett (5. ábra)



5. ábra. Radiális (bal) és tangenciális (jobb) vízsugaras esztergálással megmunkált felületek (hosszelötolás $3 \mathrm{~mm} / \mathrm{min}$, fordulatszám $300 \mathrm{l} / \mathrm{min}$ )

Az egy próbadarabon elhelyezett felületek révén vizuálisan is jól összehasonlíthatóvá vált a kétféle esztergálási módszer. 


\section{Kísérleti eredmények}

A forgácsolásokat követően meghatároztuk a leválasztott anyagréteg vastagságát. Ennek változását a 6. ábra mutatja.

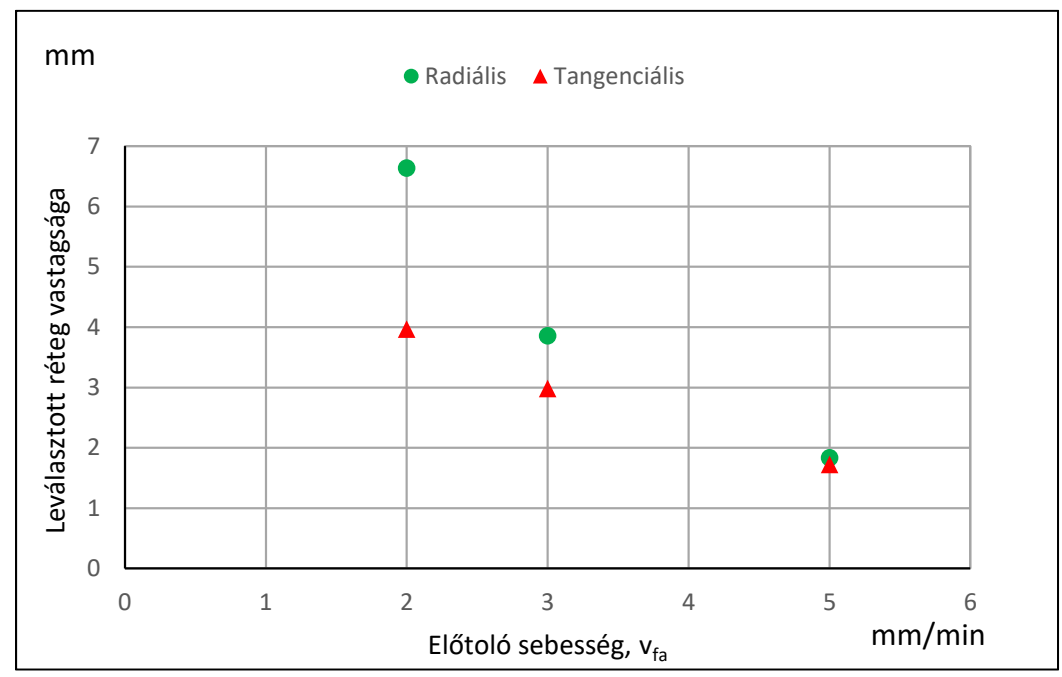

6. ábra. Leválasztott anyagréteg vastagsága radiális és tangenciális vizsugaras esztergálásnál az elötolás függvényében (motorfordulat $300 \mathrm{l} / \mathrm{min}$, abraziv áram $400 \mathrm{~g} / \mathrm{min}$ )

A 6. ábrából megállapítható, hogy a radiális esztergálással valamennyi esetben vastagabb anyagréteg távolítható el ugyanolyan technológiai paraméterek esetén, vagyis anyagleválasztás szempontjából hatékonyabb.

A 7. ábra a felületi érdesség paraméterei közül az átlagos felületi érdesség $(\mathrm{Ra})$ változását mutatja a 6. ábrának megfelelő kísérleti beállítások mellett.



7. ábra. Az átlagos érdesség változása radiális és tangenciális vízsugaras esztergálásnál az előtolás függvényében (motorfordulat $300 \mathrm{l} / \mathrm{min}$, abraziv áram $400 \mathrm{~g} / \mathrm{min}$ ) 
A 7. ábra alapján megállapítható, hogy kedvezöbb érdességü megmunkált felületek a tangenciális vízsugaras esztergálással nyerhetők. Az érdesség változása az előtolás függvényében nem egyértelmü.

\section{4. Összefoglalás}

Az eredményeket összegezve, a kétféle vízsugaras esztergálás összehasonlítására irányuló kísérletek alapján az alábbi megállapítások tehetők:

- Azonos technológiai paraméterekkel végzett megmunkálásokkor a radiális eljárással nagyobb leválasztási hatékonyság érhető el.

- A leválasztott anyagréteg vastagsága az előtolás növelésével egyértelműen csökken.

- A felület átlagos érdessége a tangenciális eljárás esetén kisebb, az előtolás függvényében nem egyértelmü változást mutat.

- A tangenciális eljárás esetén a beállított fogásmélység nem azonos a ténylegesen leválasztott réteg vastagságával.

Összességében elmondható, hogy abrazív vízsugaras esztergálással az anyagok jól megmunkálhatók, az elöírt méret betartása azonban nem kellő pontosságú. Tangenciális abrazív vízsugaras esztergálással kedvezőbb felületminőség, radiális eljárással nagyobb anyagleválasztási hatékonyság érhető el. A lejátszódó folyamatok tisztázásához további vizsgálatok szükségesek.

\section{Köszönetnyilvánítás}

A cikkben ismertetett kutató munka az EFOP-3.6.1-16-2016-00011 jelü „Fiatalodó és Megújuló Egyetem - Innovatív Tudásváros - a Miskolci Egyetem intelligens szakosodást szolgáló intézményi fejlesztése" projekt részeként - a Széchenyi 2020 keretében - az Európai Unió támogatásával, az Európai Szociális Alap társfinanszírozásával valósul meg.

\section{Irodalom}

[1] Li, W., Zhu, H., Wang, J., Yasser M. A., Huang, C.: An investigation into the radial-mode abrasive waterjet turning process on high tensile steels, International Journal of Mechanical Sciences, 77 (2013), pp. 365-376 https://doi.org/10.1016/j.ijmecsci.2013.05.005

[2] Liu, D., Huangn, C., Wang, J., Zhu, H., Yao, P., Liu, Z. W.: Modelling and optimization of operating parameters for abrasive waterjet turning alumina ceramics using response surface methodology combined with Box-Behnken design, Ceramics International, 40 (2014), pp. 7899-7908 https://doi.org/10.1016/j.ceramint.2013.12.137

[3] Manu, R., Babu, N. R.: An erosion-based model for abrasive waterjet turning of ductile materials, Wear; 266: 1091-7. (2009) https://doi.org/10.1016/j.wear.2009.02.008

[4] Zohoor, M., Zohourkari, I., Cacciatore, F., Annoni, M.: Influence of machining parameters on part geometrical error in abrasive waterjet offset-mode turning, Proceedings of the Institution of Mechanical Engineers, Part B: Journal of Engineering Manufacture, Volume: 229 issue: 12, pp. 2125-2133., (2014) https://doi.org/10.1177/0954405414548462

[5] Axinte, D. A., Stepanian, J. P., Kong, M. C., McGourlay, J.: Abrasive waterjet turning - An efficient method to profile and dress grinding wheels, International Journal of Machine Tools \& Manufacture.; 49: 351-6. (2009) https://doi.org/10.1016/j.ijmachtools.2008.11.006

[6] Kovacevic, R., Hashish, M., Mohan, R., Ramulu, M., Kim, T. J., Geskin, E. S.: State of the art of research and development in abrasive waterjet machining, ASME Journal of manufacturing Science and Engineering; 119: 776-85. (1997) https://doi.org/10.1115/1.2836824 
[7] Mazurkiewicz, M.: A manufacturing tool for a new century, Journal of Materials Processing Technology, 106: 112-8. (2000) https://doi.org/10.1016/S0924-0136(00)00600-2

[8] Kun-Bodnár, K., Kundrák, J., Maros, Z.: Machining of rotationally symmetric parts with abrasive waterjet cutting, IOP Conference Series: Materials Science and Engineering, 448 012053, (2018) https://doi.org/10.1088/1757-899X/448/1/012053 